\title{
Offensive Expression and the Workplace
}

\section{MEGAN PEARSON}

\section{ABSTRACT}

In this article I argue that freedom of expression is an important right even within the employment context. I contend that there should be a presumption in favour of free expression even if the expression is offensive, particularly if it involves a matter of public debate. However, the interests of colleagues and employers should be taken into account and may be decisive. Where expression takes place outside work, employees should only be subject to disciplinary action if there is a clear link between their employment and the expression. I consider the law relating to these issues in the contexts of harassment, unfair dismissal and discrimination on the grounds of religion and belief.

\section{INTRODUCTION}

Given the diversity of opinions existing in a pluralist society on almost any subject, it is likely that conversations in the workplace may turn to controversial matters and that employees may sometimes express their views in a way which their colleagues find highly offensive. Some employees may also see it as their religious duty to proselytise in the workplace or wish to persuade others of the truth of their political views. Such speech may be perceived by colleagues as irritating at best and as offensive, even degrading, at worst. Some employers may also wish to control expression by their employees which takes place outside work, on the grounds that it affects the employer's trust in an employee's abilities, leads to workplace disharmony or affects an employer's

* PhD Candidate in Law, London School of Economics and Political Science m.r.pearson@lse.ac.uk. 
reputation. An employee's freedom of expression may therefore be infringed for numerous reasons, raising complex issues as to how to protect this right whilst giving due consideration to the rights and interests of others.

\section{THE IMPORTANCE OF FREEDOM OF EXPRESSION}

As is well known, in Handyside $v U K$ the European Court of Human Rights (ECtHR) stated that, 'freedom of expression...is applicable not only to 'information' or 'ideas' that are favourably received or regarded as inoffensive or as a matter of indifference, but also to those that offend, shock or disturb'.1 Simply because expression takes place in a work context does not mean that this maxim should be ignored. Work life is usually significant to an individual, both in terms of time and in its importance to a person's sense of identity. Furthermore colleagues may make up a substantial proportion of those with whom a person regularly interacts. Like any expression, expression at work may therefore be important for an individual's self-development or sense of autonomy. ${ }^{2}$ This may be especially true for expression relating to political or religious views, which may be extremely important to a person's sense of identity, but which may be particularly controversial.

Workplace expression is also important from the perspective of broader society. The classic, although problematic, argument for freedom of speech is that of the 'marketplace of ideas': the argument that through unfettered free speech the truth will emerge, ${ }^{3}$ although experience certainly does not necessarily demonstrate the truth of this idea. ${ }^{4}$ This argument is linked to perhaps a more persuasive one, which Barendt

\footnotetext{
1 (1979-80) 1 EHRR 737, 754. Although this maxim is not necessarily always complied with, as the Court's conclusion in the case in fact demonstrates.

${ }^{2}$ L. Vickers, Freedom of Speech and Employment (Oxford: OUP, 2002) 17.

3 This idea is particularly associated with John Milton and John Stuart Mill.

${ }^{4}$ See eg A.I. Goldman, Knowledge in a Social World (Oxford: OUP, 1999) Ch 7.
} 
refers to as 'the argument from citizen participation in a democracy'. ${ }^{5}$ This argument holds that free expression is required in order to hold governments to account and for individuals to contribute to political decisions.

A workplace is a 'logical' place for discussion about political and social matters. ${ }^{6}$ In comparison to many other places where people meet, it may be more diverse in terms of political and religious views, age and other characteristics. Participation in workplace discussions may also provide greater exposure to differing ideas than more formal methods for receiving information such as the media. This is particularly so given that use of the media is subject to a confirmation bias. Empirical research has demonstrated that people tend not only to choose print or online media that agree with their preexisting views, but also choose to read those news stories that do so too. ${ }^{7}$ To point out the value of workplace expression on social or political issues is not to overly romanticise it: evidently expression may be ill-informed or bad-tempered, and may not be welcomed by those to whom it is addressed. This situation is though hardly unique to the employment context.

The presumption in favour of free expression is even stronger where an employer seeks to control expression that takes place out of work time. Evidently this places a far more serious burden on the right to freedom of expression. The fear of losing a job or being subject to other disciplinary measures may have a severe chilling effect on such expression, thus affecting both the free discussion of ideas and an employee's opportunity for self-development.

\section{THE IMPORTANCE OF OTHER INTERESTS}

\footnotetext{
5 E. Barendt, Freedom of Speech (Oxford: OUP, 2005) 18-21.

${ }^{6}$ E. Volokh, 'Freedom of Speech and Workplace Harassment' (1991) 39 UCLA L Rev 1791, 1849.

${ }^{7}$ See eg S. Knobloch-Westerwick, 'Selective Exposure and Reinforcement of Attitudes and Partisanship before a Presidential Election' (2012) 62 Journal of Communication 628.
} 
While freedom of expression is an important right, even within the employment context, there are countervailing interests to this. There can clearly be no right for an employee to say anything at any time and in any form. Although the workplace may be an important forum for expression, this is of course not its main purpose. An employer has legitimate interests in the economic and efficient functioning of its business. ${ }^{8}$ Permitting offensive expression by employees may well distract or demotivate employees, especially if it is aimed at particular colleagues. Even out of work expression can have spill over effects into the workplace, causing disruption and upset.

Serious or prolonged forms of offensive speech may also amount to harassment. Under the Equality Act 2010 s.26, harassment takes place if a person engages in unwanted conduct related to a protected characteristic, and the conduct has the purpose or effect of violating a person's dignity, or creating an intimidating, hostile, degrading, humiliating or offensive environment for them. In considering this, whether it is reasonable for the conduct to have this effect, the perception of the 'victim' and the other circumstances of the case must be taken into account.

Harassment clearly causes harm to those it is directed towards, causing considerable stress and potentially having serious effects on a person's mental health. Employees can be particularly vulnerable to such expression since they may feel unable to challenge such behaviour, particularly if it comes from senior employees, and typically have little opportunity to avoid it (the 'captive audience' problem). ${ }^{9}$ Moreover harassment does not only affect the individuals it is aimed at. Prohibiting harassment also challenges group-based disadvantage and is an important aspect of tackling discrimination. ${ }^{10}$ If a person subjected to harassment finds the situation so intolerable that they feel they must move employment, this not only places a great burden on them, but also has damaging effects on efforts to break down discriminatory barriers in

\footnotetext{
8 Whether this is a commercial activity or not.

${ }^{9}$ Although as Volokh points out the problem of the captive audience is not considered vital in other contexts: Volokh, n. 6 above, 1832-8.

10 See eg S. Fredman, Women and the Law (Oxford: Clarendon Press, 1997) 320-331.
} 
employment. If harassment is left unchecked it can function in much the same way as a status based bar, discouraging some groups of employees from entering particular fields. Even if its effects are not this severe, it 'forces some groups of employees to work under real psychological burdens that other groups need not bear'.11

Employers have their own interest in preventing harassment, not least because they have vicarious liability for acts performed 'in the course of employment', unless they have taken all reasonable steps to prevent such acts. ${ }^{12}$ Whilst not all offensive speech will amount to harassment, employers may err on the side of caution to prevent legal liability. They may also wish to protect their employees from a much greater ranger of speech in order to create a harmonious working environment and to ensure the recruitment and retention of employees.

As well as causing disruption inside the workplace, offensive expression may harm an employer's outside interests by causing them embarrassment or by affecting the image or reputation they wish to promote to outsiders. For example, if discriminatory expression is permitted, this may affect the employer's interest in being seen to have a commitment to diversity and non-discrimination. As part of this commitment, an employer may seek public acknowledgment from an outside body that prescribed standards have been met $^{13}$ and an employee that expresses discriminatory views may be seen as threatening this determination. Action may also be taken by public sector employers to ensure that they comply with the equality duty under the Equality Act 2010 s.149.14 Even expression outside the workplace may become associated with an employer and so it may be called on to distance itself from such opinions, perhaps by

\footnotetext{
11 Volokh, n. 6 above, 1846.

12 Equality Act 2010 s.109.

13 For example the gay rights campaigning organisation Stonewall publishes a list of Top 100 Employers: 'Stonewall Top 100 Employers 2014'

<http://www.stonewall.org.uk/at_work/stonewall_top_100_employers/default.asp> accessed 4 July 2014.

14 This requires a public authority to, inter alia, have due regard to the need to 'eliminate discrimination, harassment, victimisation and any other conduct that is prohibited by or under this Act' and 'to foster good relations between persons who share a relevant protected characteristic and persons who do not share it' in the exercise of its functions.
} 
disciplining the employee. Given the widespread use of social media, where views can easily be distributed to large numbers of people, comments can quickly become public. The capacity to cause embarrassment to employers is therefore great.

\section{ECHR LAW AND RIGHTS IN EMPLOYMENT}

While in only a few cases are labour rights specifically mentioned in the ECHR, the European Court of Human Rights (ECtHR) has made it clear that the Convention does have relevance within the employment context, protecting among other things, rights to privacy, ${ }^{15}$ freedom of religion ${ }^{16}$ and freedom of association. ${ }^{17}$ Any restriction of the right to freedom of expression should be considered through this lens.

This is demonstrated by the ECtHR's decision in Redfearn $v$ UK. ${ }^{18}$ The case involved a bus driver who was dismissed because he was a member of the British National Party (BNP) and had stood for election as a local councillor for the party. His job primarily involved transporting children and adults with physical and/or mental disabilities. His claims under domestic law failed. He could not bring a claim for unfair dismissal as he did not have the requisite qualifying period of employment. His, rather unconvincing, claim that he had been discriminated against 'on the grounds of race' was rejected by the Court of Appeal, although it had been successful in the Employment Appeal Tribunal. ${ }^{19}$ The ECtHR held that it was a violation of Article 11 (freedom of association) that he did not have an effective mechanism to challenge his dismissal for his political views, although it did not decide that his dismissal was a violation in itself. Eweida $v U K^{20}$ similarly demonstrates that interferences with a person's freedom to

\footnotetext{
15 Niemietz v Germany (1993) 16 EHRR 97; Copland v UK (2007) 45 EHRR 37.

16 Eweida $v$ UK (2013) 57 EHRR 231.

${ }^{17}$ ASLEF v UK (2007) 45 EHRR 34.

18 (2013) 57 EHRR 2.

19 [2005] IRLR 744 (EAT); [2006] EWCA Civ 659, [2006] ICR 1367.

${ }^{20}$ Eweida n. 16 above.
} 
manifest religious beliefs during employment can constitute a violation of Article 9 (freedom of thought, conscience and religion).

Human rights should not and do not end at the office door. To do so would create a fundamental imbalance between the employer and employee and would, as Gunn put it, make 'fundamental rights subject to mere contractual waiver'. ${ }^{21}$ However, gaining the protection of ECHR rights within the work context may be complex, even if an employee has been dismissed or subject to other disciplinary action. The law relating to unfair dismissal will be addressed further below. First though I will consider the situation where employers have used the right of freedom of expression as a shield to defend themselves against harassment claims, since these cases set the parameters of permissible workplace speech.

\section{HARASSMENT CLAIMS AND FREEDOM OF EXPRESSION}

There has been much discussion in the US as to whether laws prohibiting harassment infringe the First Amendment's guarantee of freedom of speech. ${ }^{22}$ Evidently, given that harassing speech must be prohibited by employers, and that there may well be a further 'chilling effect' as employers seek to avoid liability, it is important to draw the parameters of this right in a way which does not unduly restrict freedom of expression. To date, there appears to be less concern on this point in the UK. Hepple's point that 'freedom of expression is the dog that did not bark in the development of UK law on harassment' 23 still holds at least partially true. This difference has much to do with broader differences in the attitude towards freedom of expression between the two

21 T.J. Gunn, 'Adjudicating Rights of Conscience under the European Convention on Human Rights', in J. Van der Vyver and J. Witte (eds), Religious Human Rights in Global Perspective: Legal Perspectives (The Hague: Martinus Nijhoff, 1996).

${ }^{22}$ Eweida n. 16 above.

${ }^{23}$ B. Hepple, 'Freedom of Expression and the Problem of Harassment' in J. Beatson and Y. Cripps (eds), Freedom of Expression and Freedom of Information: Essays in Honour of Sir David Williams (Oxford: OUP, 2000). 
jurisdictions. In particular, the US approach is highly suspicious of content-based restrictions on speech, including prohibitions on hate speech, ${ }^{24}$ and tends to disavow tests which balance the interest in free speech against other aims, in direct contrast to the structure of Article 10 ECHR. ${ }^{25}$

Nevertheless, some of the points raised by US writers are still pertinent. The major concern has been that the vagueness and unpredictability of the law, and the subjective element in considering the effect the speech has on employees, mean that a great deal of speech will be prohibited, when this would receive high protection in other contexts. ${ }^{26}$ It has also been claimed that harassment law, particularly sexual harassment law, has a 'sanitizing' effect, resting on a rationalist management style which does not break down gender or other barriers, but rather is applied unequally, treating those from ethnic minorities or who are gay more severely. ${ }^{27}$ Of course though, as discussed above, prohibitions on harassment are necessary to protect individuals and to break down systemic discrimination.

Despite these concerns, the limited number of Employment and Employment Appeal Tribunal cases on this topic appear so far to demonstrate sufficient concern for free speech. They have not prohibited expression which, while potentially offensive, is either an important matter of public debate or only causes trivial harm. This latter point is demonstrated by Heafield $v$ Times Newspapers. ${ }^{28} \mathrm{~A}$ subeditor claimed that he had been subject to harassment on the ground of religion when an editor shouted across a newsroom, 'Can anyone tell what's happened to the fucking Pope?', in order to chase a delayed article relating to allegations that the Pope had protected a priest accused of paedophilia. The EAT held that this did not amount to harassment because it did not violate Heafield's dignity or create an adverse atmosphere for him. In doing so it held

\footnotetext{
${ }^{24}$ See eg R.A.V v St. Pauls 505 US 377 (1992).

$25 \mathrm{~J}$. Weinstein, 'An Overview of American Free Speech Doctrine and Its Application to Extreme Speech' in I. Hare and J. Weinstein (eds), Extreme Speech and Democracy (Oxford: OUP, 2009).

${ }^{26}$ Volokh n. 6 above.

${ }^{27}$ V. Schultz, 'The Sanitized Workplace' (2003) 112 Yale LJ 2061.

28 [2013] UKEATPA/1305/12/BA.
} 
that the case was evidently 'not ill-intentioned or anti-Catholic or directed at the Pope or at Catholics'.

Whilst the subeditor may not have expressed himself in the most tactful way, the Employment Appeal Tribunal reached the correct decision. Mere incivility should not be sufficient to ground a harassment claim. Given that this was a one-off remark in the heated environment of a newsroom under a strict deadline, it is difficult to see how this could have violated Heafield's dignity or created a hostile or degrading environment.

The speech involved in Heafield was rather trivial. However, employment related speech can also be on highly important political matters which are usually considered to be at the core of free speech protection. This was the case in Fraser $v$ University and College Union. ${ }^{29}$ The nature of the case is somewhat unusual. Fraser, a teacher at secondary and higher education level, argued that his union was institutionally antiSemitic because of its criticism of Israel in its policies towards Palestine. He argued this amounted to harassment on the grounds of race and religion. More specifically it was alleged, among other things, that the Union's actions relating to a motion passed in the Union's Congress to boycott Israeli academic institutions and other motions censuring Israel's activities; its management of an online forum for members of the Union; and the invitation of a speaker who was found by the South African Human Rights Commission to have committed anti-Semitic hate speech, ${ }^{30}$ amounted to harassment.

Only the final complaint was accepted as amounting to harassment, and this claim was held to be out of time. The rest of the complaints were firmly rejected. As a preliminary point, the case faced a problem because harassment is only prohibited on certain grounds. While Fraser claimed that the harassment was on the grounds of race, the Union's criticisms were of Israel's policies. While there is evidently a possible relationship between criticism of Israel and anti-Semitism, it is hard to see how Zionism

\footnotetext{
29 [2013] ET/2203290/2011.

${ }^{30}$ Although the Tribunal accepted that at the time that the Union was only aware the complaint was awaiting adjudication.
} 
or an attachment to the state of Israel in itself could be a protected characteristic. Whilst there may have been a better argument that it constituted indirect discrimination, this argument was not put forward in the case.

More importantly for present purposes, the Tribunal held that even the subjective part of the harassment case had not been made out since it had not been demonstrated that Fraser felt that an 'intimidating, hostile, degrading, humiliating or offensive environment' had been created by the Union's actions. A feeling of 'upset' was not sufficient. It was also pointed out that as an activist, Fraser had to expect criticism and so it was difficult to see a response to his activism as unwanted. Finally, it was held that even if this had been a borderline case, the importance of free speech would have tipped the balance. The Union was debating a matter of important public interest, which was part of its usual activities. While, as it accepted, the Union would in some circumstances have to withdraw some motions, to be required to withdraw a matter which was the subject of legitimate public interest from democratic discussion, would be a draconian step. This was so even, and perhaps in fact even more so, when the issue was controversial.

This case is far from being a typical harassment case and so cannot be used as a reliable guide to other cases. ${ }^{31}$ Nevertheless it is still an illustration of how freedom of expression and in particular the right of individual and collective political expression can be protected without unduly weakening the prohibition on harassment. However, even if harassment law does not interfere too greatly with the right of freedom of expression in the cases which come to trial, it is still possible that the very existence of harassment law may give rise to a 'chilling effect' which poses a risk to the right of free expression. As Volokh points out, this effect may be significant because 'employers derive no benefit from their employees' offensive speech, but must bear liability for it.'32

\footnotetext{
${ }^{31}$ And is of course only an Employment Tribunal case.

32 Volokh n. 6 above, 1812.
} 
While the prohibition of harassment requires an employer to prohibit certain kinds of expression, a greater risk to freedom of expression may result from the discretionary limits placed on employees' expression by employers, which may be much broader than is required by law. Employees may therefore seek recompense for dismissals which they consider breach their Convention rights. It is to the question of the limits of permissible restrictions of freedom of expression that this article now turns.

\section{UNFAIR DISMISSAL AND HUMAN RIGHTS LAW}

Employees may bring a claim for unfair dismissal if they have a two-year qualifying period of employment or if the expression relates to an employee's political opinions or affiliation. ${ }^{33}$ However, the application of Convention rights within this context is not straightforward. The leading case on the interrelationship between the ECHR and unfair dismissal is $X v Y{ }^{34} \mathrm{X}$ was dismissed when his caution for gross indecency for engaging in sexual activities in a public toilet was revealed after a routine check at work. The Court of Appeal held that, as a tribunal is considered a public body under Human Rights Act 1998 s.6, an Employment Tribunal is under an obligation to take into account Convention rights in considering whether a dismissal was fair or unfair for the purposes of the Employment Rights Act 1996 s.98. Mummery LJ laid down a five-stage process for considering Convention rights within employment, which runs as follows:

1. Do the circumstances of the dismissal fall within the ambit of one or more of the articles of the Convention? If they do not, the Convention right is not engaged and need not be considered

2. If they do, does the state have a positive obligation to secure enjoyment of the relevant Convention right between private persons? If it does not, the

\footnotetext{
33 The specific problem identified in Redfearn has been addressed and so there now is no qualifying period of employment where a person is dismissed because of her 'political opinions or affiliation.' Employment Rights Act 1996 s.108. as amended by the Enterprise and Regulatory Reform Act 2013 s.13 ${ }^{34}$ [2004] EWCA Civ 662, [2004] ICR 1634.
} 
Convention right is unlikely to affect the outcome of an unfair dismissal claim against a private employer

3. If it does, is the interference with the employee's Convention right by dismissal justified?

4. If it is not, was there a permissible reason for the dismissal under the ERA which does not involve unjustified interference with a Convention right? If there was not, the dismissal will be unfair for the absence of a permissible reason to justify it

5. If there was, is the dismissal fair, tested by the provisions of section 98 of the ERA, reading and giving effect to them under section 3 of the HRA so as to be compatible with the Convention right?35

In the final analysis, X's case failed at the first step as it was held that his conduct was not part of his private life. Article 8 was therefore held not to be engaged, although Brooke LJ did express some misgivings as to this conclusion.

Although not significant for the facts of this case, while the ECHR is not directly applicable in cases between private parties, this test importantly appears to require similar standards to be applied between public and private employers, given the state's positive obligations to ensure its law is in conformity with the Convention. It seems unlikely that cases would or should be decided differently on this basis. ${ }^{36}$

The relationship between unfair dismissal law and the right to freedom of expression was considered in Pay v Lancashire Probation Service, ${ }^{37}$ which was decided shortly before $X v Y$. A probation officer who worked with sex offenders was dismissed because it had come to light, following an anonymous fax to the police, that he performed what was described as a 'fire act' at fetish clubs, and was a director of a company that sold products connected with bondage and sadomasochism. It was considered that public knowledge of this would damage the Probation Service's reputation. Pay claimed that his dismissal was a violation of his right to respect for his private life under Article 8 ECHR and of his freedom of expression.

\footnotetext{
35 Ibid. 1653-4

${ }^{36}$ L. Vickers, 'Unfair Dismissal and Human Rights' (2004) 33 ILJ 52.

37 [2004] ICR 187 (EAT).
} 
The Employment Appeal Tribunal accepted that the Tribunal had a duty to interpret whether or not there had been an unfair dismissal in line with his Convention rights, but it was held that his right to respect for his private life was not infringed because the activities took place in public. His request for an appeal was refused on the basis that the then recent decision in $X v Y$ negated his chance of success. Pay then took his case to the ECHR, ${ }^{38}$ which 'proceeded on the assumption' that Article 8 was applicable and held that Art 10 was applicable, but concluded that the infringement was justified because of the interests of the Probation Service, given the nature of his work and the risk that knowledge of his activities would become public.

While the domestic and European courts considered similar points and reached similar conclusions, there are differences in their reasoning with respect to the protection given to freedom of expression. As Collins and Mantouvalou point out, in considering whether a dismissal was fair under the Employment Rights Act 1996 the question is not whether the Employment Tribunal would have made the same decision, but whether the decision was reasonable. ${ }^{39}$ This has been interpreted as requiring consideration of whether the employer's decision was within 'the range of reasonable responses' it could have taken. ${ }^{40}$ There is a distinct difference in emphasis between taking into account concerns about freedom of speech in a consideration of reasonableness, especially such an attenuated assessment of reasonableness, and a starting point that requires all interferences with freedom of speech to be justified. ${ }^{41}$ This may well lead to a watered down protection of rights within the employment context.

\footnotetext{
38 (2009) 48 EHRR 15.

${ }^{39}$ H. Collins and V. Mantouvalou, 'Private Life and Dismissal: Pay v UK' (2009) 38 ILJ 133.

${ }^{40}$ HSBC Bank plc v Madden [2001] 1 All ER 550

${ }^{41}$ P. Elias and J. Coppel, 'Freedom of Expression and Freedom of Religion: Some Thoughts on the Glenn Hoddle Case' in J. Beatson and Y. Cripps (eds), Freedom of Expression and Freedom of Information: Essays in Honour of Sir David Williams (Oxford: OUP, 2000); H. Collins, 'The Protection of Civil Liberties in the Workplace' (2006) 69 MLR 619.
} 
Although not relevant to the main argument of this article, the Court of Appeal's conclusion that there was no interference with X's private life because his actions took place in public rests on an impoverished view of this concept. A rigid distinction relying on a dichotomy between private and public space is unrealistic. The ECtHR has recognised a right to privacy for acts that take place wholly in public, ${ }^{42}$ and Pay's acts took place in at least a semi-private environment. Furthermore, even the ECtHR's decision can be criticised for not sufficiently protecting rights of expression and privacy. The justification put forward rested on a general fear that his activities would lead to a loss of public confidence in the probation service, without real consideration of how they affected his work. The case has unfortunate overtones of Saunders v Scottish National Camps Association 43 in its perception of sexual minorities as deviant. ${ }^{44}$ However, it is arguable that Pay should have taken more care to ensure that photographs of him performing would not be publicly available.

\section{WORKPLACE EXPRESSION AND THE RIGHT TO MANIFEST A RELIGION OR}

\section{BELIEF}

If the expression relates to an aspect of a person's religion or belief, an employee may not only have an unfair dismissal claim but also a claim that the restriction on the expression amounts to indirect religious discrimination. In considering this, the right to manifest a religion or belief under Article 9 should be taken into account. 45 This is a greater right than may be immediately apparent. 'Belief' has been interpreted broadly

\footnotetext{
${ }^{42}$ Eg Peck v UK (2003) 36 EHRR 41; Von Hannover v Germany (2005) 40 EHRR 1 . This is also the case in domestic law, eg Campbell v Mirror Group Newspapers Ltd [2004] UKHL 22, [2004] 2 AC 457.

43 [1980] IRLR 174. Saunders was a gay man employed as a handyman at a children's camp. It was held that dismissing him because of his sexual orientation was a course open to a reasonable employer.

${ }^{44}$ B. Chatterjee, 'Pay v UK, the Probation Service and Consensual BDSM Sexual Citizenship' (2012) 15 Sexualities 739.

${ }^{45}$ Mba v Merton LBC [2013] EWCA Civ 1562, [2014] 1 All ER 1235.
} 
for the purposes of the Equality Act 2010,46 to include for example beliefs in man-made climate change and environmentalism ${ }^{47}$ and in an ethos of public service broadcasting. ${ }^{48}$ No qualifying period of employment is needed to bring this claim. Such a claim would have been unlikely to provide redress in situations such as in Redfearn though, since support for a political party is not considered to amount to a 'belief'. Support for the BNP's policies would also be likely to be excluded, since in order to be counted as a belief it must be 'worthy of respect in a democratic society and not incompatible with human dignity'. ${ }^{49}$ Such restrictions on 'belief' may well be appropriate: indeed the concept of belief may already have been stretched beyond its comfortable meaning.

In a development which may at first sight seem rather paradoxical, cases have arisen where employees have argued that they have been subject to discrimination because they have been dismissed for sharing religious views which are discriminatory and offensive towards gay people. While these cases work better conceptually as claims of a violation of religious freedom under Article 9, rather than discrimination claims, they are still understandable within this context. The argument runs as follows: since Christians belonging to certain denominations are more likely to have particular (negative) views about homosexuality and related matters such as gay marriage, and also to believe that they are under a religious obligation to share these beliefs with others, limiting their ability to do so places them at a particular disadvantage. It therefore amounts to indirect discrimination.

These issues were considered in Apelogun-Gabriels $v$ London Borough of Lambeth.50 The claimant, an Evangelical Christian, ran a prayer meeting at work with the consent of his employers. After one meeting he distributed a document with extracts from the Bible to colleagues who had not attended the meeting. The first headings on

\footnotetext{
${ }^{46}$ And the preceding Employment Equality (Religion or Belief) Regulations 2003.

47 Grainger plc v Nicholson [2010] 2 All ER 253 (EAT).

${ }^{48}$ Maistry v BBC (2011) ET/1313142/2010.

${ }^{49} R$ (Williamson) $v$ Secretary of State for Education and Employment [2005] UKHL 15, [2005] 2 AC 246.

50 (2006) ET/2301976/05.
} 
this document were 'sexual activity between members of the same sex is universally condemned' and 'male homosexuality is forbidden by law and punished by death'. As a result of this he was dismissed. The Tribunal held that the Council had not subjected him to either direct or indirect religious discrimination or unfairly dismissed him.

Hambler, although he seems to agree with the result, criticises the Tribunal's decision. He argues that the Tribunal, by stating that it 'considered the wording of the selected extracts from the Bible involved to be uncompromising and strongly condemnatory of homosexual conduct', comes 'perilously close to condemning the Bible itself', because 'it is not easy to find references to homosexuality within the plain meaning of the Bible which are not in some way "uncompromising and strongly condemnatory"'. ${ }^{51} \mathrm{He}$ argues that this contradicts previous caselaw ${ }^{52}$ which does not 'seek to exclude "homophobic verses" of the Bible from acceptable discourse'.53

However, the Tribunal's point seems only to be the unobjectionable one of describing the nature of the expression and considering how 'hostile', 'degrading' or 'offensive' it is, rather than an attempt to exclude conservative religious viewpoints from the field of acceptable beliefs. In any case, there can be no protection of expression only because it is taken from the Bible. To do so would violate basic rights of nondiscrimination and religious freedom, since it would privilege Christianity above other religious or non-religious beliefs. ${ }^{54}$ While interferences with religious expression should be strictly assessed, it could clearly be justifiable in some contexts for employees to be dismissed for quoting parts of the Bible. For example, parts of the New Testament such as the Jewish crowds' demand to have Jesus crucified have been used historically to

\footnotetext{
51 A. Hambler, 'A Private Matter? Evolving Approaches to the Freedom to Manifest Religious Convictions in the Workplace' (2008) 3 Religion and Human Rights 111, 131.

52 Hambler refers to R (Amicus) v Secretary of State for Trade and Industry [2004] EWHC 860 (Admin), [2007] ICR 1176. Further examples are Ladele v Islington LBC [2009] EWCA Civ 1357, [2010] 1 WLR 955 and Re Christian Institute's Application for Judicial Review [2007] NIQB 66. ${ }^{53}$ Hambler n. 51 above, 131.

${ }^{54}$ As Sir James Munby stated, 'Reliance upon religious belief, however conscientious the belief and however ancient and respectable the religion, can never of itself immunise the believer from the reach of the secular law': J. Munby, 'Law, Morality and Religion in the Family Courts' (2014) 16 Ecc LJ 131, 138.
} 
justify appalling anti-Semitism. ${ }^{55}$ If an employee repeatedly referred to this in order to criticise a Jewish colleague, the employer would be justified in dismissing her.

It could be argued that a final warning would have been more appropriate than dismissal, given that this was the first incident of such behaviour. Evidently, dismissal was a great interference with Apelogun-Gabriels' freedom of expression. However, the views expressed were highly inflammatory, given in particular that they could be interpreted as calling for violence against gay people. They were unsought by his colleagues who did not attend the prayer meeting, and had led to complaints. Although this was the first time that Apelogun-Gabriels had shared such views at work, after carrying out a disciplinary hearing, his employer was unconvinced that similar behaviour would not reoccur. His colleagues' interest in not being faced with such material, together with the interests of the employer in maintaining a nondiscriminatory workplace therefore outweighed the interference with the claimant's right. The decision reached was justifiable.

Haye $v$ London Borough of Lewisham ${ }^{56}$ raises similar points, although the speech was directed outside the organisation rather than internally. Haye sent an email whilst at work and from her work account to the Lesbian and Gay Christian Movement (LGCM). In it she stated that being gay is a sin, that LGCM was 'deceiving' people into believing that it was acceptable to be gay and a Christian and urged the reader 'to repent and turn from your sinful ways before its [sic] too late... Hell is not a nice place'. Haye was dismissed for sending an email containing homophobic views and for bringing the council into disrepute. She claimed she had been either directly or indirectly discriminated against because of her religious beliefs and that she had been unfairly dismissed. She believed that it was part of her religious duty to 'spread the Christian message to other Christians'.

\footnotetext{
55 See eg D. MacCulloch, Christianity: The First Three Thousand Years (London: Penguin, 2010) $92-$ 3.

${ }^{56}$ (2010) ET 2301852/2009.
} 
The Tribunal held she had not been directly discriminated against since she was not dismissed because of the Christian nature of the email but because of its offensiveness. This seems straightforward: there is no evidence that if the email had been sent by anyone with a different or no faith they would have been treated differently.

The Tribunal also held there was no indirect discrimination, either because she could still 'witness' to people outside work and thus she was not put at a disadvantage, or because the council had a proportionate means of achieving a legitimate aim. The first argument is unsatisfactory, although this is probably explained by the fact that the submissions on indirect discrimination were described as 'very vague'. Whether Haye could witness to people outside work and therefore manifest her beliefs in other ways was not particularly relevant to whether the interference with her religious practice in her employment was proportionate. Such reasoning was not however unusual. Before the ECtHR's decision in Eweida $v U K^{57}$ it had been held that there was no interference with Article 9 where an employee could resign and thus avoid conflicts between her religious views and employment obligations. ${ }^{58}$ This idea had though been severely criticised and was reconsidered in Eweida.

A better argument, which is suggested in the decision, is that while Lewisham's policy may have put evangelical Christians at a disadvantage, since it made it more difficult for them to fulfil their religious duty of evangelism, preventing such vehement views from being spread from the council's email system was fully justifiable. As the Tribunal stated, 'on any objective view, it is highly offensive, homophobic and the language is aggressive and violent'. While it might be going too far to describe her email as 'violent', since it did not call for physical aggression, it certainly contained extreme views. By so vehemently criticising gay people's sexuality, it undermined the dignity of

\footnotetext{
${ }^{57}$ Eweida n. 16 above.

58 See eg Ahmad v UK (1981) 4 EHRR 126. I have previously discussed these issues in M. Pearson, 'Article 9 at a Crossroads: Interference Before and After Eweida (2013) 13 HRLR 580.
} 
those it was aimed at. It is also highly relevant that it was sent from her work email address, thus linking her views with those of her employer in the mind of an outside organisation. The only way the employer could clearly distance itself from such views was to dismiss her.

However, not all discriminatory views expressed within work should necessarily be prohibited. This issue was raised obliquely in Ladele v Islington Borough Council.59 Ladele, a registrar, sought an exemption from performing civil partnership ceremonies because of her religious belief that marriage should only be between a man and a woman and thus that it would be wrong for her to assist in creating such relationships. Other employees believed her attempts to avoid performing them were offensive and homophobic. Leaving aside the question of whether the Council should have been required to accede to her request, should her request for accommodation be protected?60

As Vickers argues, merely asking for an exemption from performing certain aspects of a role, even if this is for discriminatory reasons, 'should not without more be considered harassment, unless this has been done in an offensive manner'. ${ }^{61}$ To do so seems likely to fan the flames of what are already controversial matters and reduce the protection of free speech and freedom of religion, without necessarily providing greater protection of the non-discrimination norm.

There are crucial differences between Ladele on the one hand, and ApelogunGabriel and Haye on the other. Ladele's act was primarily inward looking. She was not seeking to proselytise but merely to claim a right for herself. Her gay colleagues were faced only with the knowledge that she strongly disapproved of gay marriage and civil partnerships for religious reasons. In contrast, Apelogun-Gabriels' and Haye's acts were outward looking and involved active proselytising of their controversial views.

\footnotetext{
${ }^{59}$ Ladele n. 52 above.

${ }^{60}$ This issue was not directly raised in the case.

${ }^{61}$ L. Vickers, 'Religious Discrimination in the Workplace: An Emerging Hierarchy?' (2010) 12 Ecc LJ 280, 296.
} 
Dismissal in both Haye and Apelogun-Gabriels was a reasonable response. Whilst there is an argument that these cases demonstrate an unsympathetic response to religious believers who wish to share their beliefs, which contrasts unfairly with the wider scope given to those who share views which are offensive to some religious people, there is no real inconsistency between the two sets of cases. Absent exceptional circumstances, the mere discussion of religious or political viewpoints should not be prohibited. Exceptions to freedom of expression and, if relevant, freedom of religion should be strictly interpreted in discrimination and unfair dismissal claims. However, this does not give the 'obdurate believer'62 carte blanche to spread discriminatory views: the rights of others must be considered. Where this expression is abusive or threatening, it is very likely to be proportionate to prohibit it.

\section{EXPRESSION OUTSIDE WORK}

Restrictions on expression outside work infringe freedom of expression and affect an employee's rights to autonomy more deeply than restrictions on speech within work. An important aspect of this right of autonomy is a right to 'a life away from work,' 63 of which freedom of expression on controversial or offensive matters is a part. Such a right leads to 'better equality between employer and employee by giving content to what it means to society for persons to be free of control over their private lives... give[s] effect to the value people attach to engagement in non-work activities meaningful to them... and cabin[s] worklife from non-work life.'64 In addition to concerns about autonomy, permitting employers to dismiss employees because of their out of work expression may greatly affect their ability to share in social or political discourses. It may thus affect the quality and extent of expression generally. As Barendt puts it, 'employees retain

\footnotetext{
62 A. Bradney, Law and Faith in a Sceptical Age (Oxford: Routledge-Cavendish, 2009).

${ }^{63}$ M. W. Finkin, 'Life Away from Work' (2005) 66 La L Rev 945.

${ }^{64}$ Ibid. 951
} 
their interest as citizens in being free to express their views and exchange information with others' ${ }^{65}$

However, it would be inappropriate for employers never to be able to discipline employees for their out of work expression. Unless it takes action, an employer may be seen as tacitly condoning an employee's views, thus lowering public trust and the trust of other employees in the employer. Particularly where the expression is at odds with the aim of the employment, it may also affect the employer's perception of the employee's ability and willingness to perform her work. Finally, if expression is targeted at particular colleagues this may undermine their dignity or create an unbearable working environment in exactly the same way as if the expression took place within employment. Nevertheless, restrictions on out of work speech should be rare. The crucial issue should be whether there is a clear link between the expression and employment, beyond vague concerns about an employers' reputation. Such a link could include situations where the speech is directly contrary to the specific aims of the employer, or an employee suggests that she has the support of the employer in making such statements.

$R$ (Raabe) $v$ Secretary of State for the Home Department 66 demonstrates the challenges these issues present clearly, although the case involved a claim for judicial review rather than unfair dismissal. Raabe, a GP, was appointed as a member of the Advisory Council on the Misuse of Drugs (ACMD). The post was unpaid. Six years before his appointment he had co-authored a short paper entitled “Gay Marriage" and Homosexuality: Some Medical Comments' that argued against the introduction of samesex marriage in Canada. It stated that gay men were extremely sexually promiscuous and engaged in risky sexual practices, that they tended to have short relationships and that this posed a risk for children brought up by gay people and, most controversially, that there was a link between homosexuality and paedophilia. It stated that 'paedophile

${ }^{65}$ Barendt n. 5 above, 490.

${ }^{66}$ [2013] EWHC 1736 (Admin). 
organisations were originally a part of the gay/lesbian coalition' and that 'the prevalence of paedophilia among homosexuals is about 10 - 25 times higher' than heterosexuals'.67 It also argued that it was possible for some gay people to change their sexual orientation by 'reparative therapy'. The Home Office became aware of the paper after Raabe had been appointed and it was the subject of media attention. Unsurprisingly, the situation led to controversy and other members of the ACMD threatened to resign if he was not dismissed. After a period of consideration, the government did so and Raabe challenged this decision.

The High Court held that dismissing him was not an interference with his freedom of religion as, while he was motivated by his religious views, he was not manifesting them. This was because the paper purported to be a neutral scientific paper rather than a religious tract, not mentioning any religious precepts at all. Raabe's religious opposition to same-sex marriage was not the issue. This reasoning is justifiable. Raabe could not argue both that the paper was not controversial because it merely reported scientific data, and that it was a manifestation of his religious views. However, it was of course an interference with his freedom of expression and so the question remains whether the interference with his rights was proportionate.

A combination of factors make his dismissal proportionate. Firstly there is the offensiveness of the paper, particularly the linking of homosexuality with paedophilia. Although presented as a scientific document, the paper was not a summary of peerreviewed studies but a polemic against gay people. Although the paper was not recent, Raabe refused to distance himself from such views. Secondly, the ACMD had only recently had a number of high-profile resignations and were anxious that more should not occur. It was also considered important for the ACMD to have the support of gay people because research had identified that there were particular patterns of drug misuse within that community.

\footnotetext{
${ }^{67}$ Ibid. [40].
} 
Furthermore, there were grounds for dismissing him which did not rest on the offensiveness of the expression. His role in the organisation was to consider evidence relating to the misuse of drugs and to suggest policies relating to this. The paper demonstrated a misuse of data in order to support his personal views. This is particularly true in relation to his claims about homosexuality and paedophilia, which did not take into account that a predilection for abusing children of one sex often does not correlate with sexual orientation towards adults. Therefore the percentage of abuse which is 'homosexual in nature', in that it is committed by an adult of the same sex as the child, does not provide information about the prevalence of paedophilia among gay people. ${ }^{68}$ Such a use of data was counter to the role he was expected to perform. This was particularly important because consideration of the ACMD's work had been dominated by discussions as to whether a 'harm reduction' approach to drug use was an appropriate strategy. While Raabe strongly opposed this, this had been the dominant approach of the ACMD.

The Home Office's decision to dismiss him is therefore justifiable. However, this case involved an unusual, very public, policy role position. In most cases employees' expression does not directly have an impact on their employment. An employee should usually be protected when they share their opinions with others outside work, even if others find these views offensive.

Smith $v$ Trafford Housing Trust ${ }^{69}$ demonstrates the risk to free expression that disciplinary action in employment can pose. A Housing Manager, who had listed his employment on his Facebook page, put a link on Facebook to a news article entitled 'Gay church 'marriages' set to get the go-ahead', with the comment 'an equality too far'. After a colleague posted 'does this mean you don't approve?' he replied:

No not really, I don't understand why people who have no faith and don't believe in Christ would want to get hitched in church the bible is quite specific that

\footnotetext{
${ }^{68}$ Ibid. [164]-[169].

${ }^{69}[2012]$ EWHC $3221(\mathrm{Ch})$.
} 
marriage is for men and women if the state wants to offer civil marriage to same sex then that is up to the state; but the state shouldn't impose it's rules on places of faith and conscience..$^{70}$

Because of these comments he was demoted to a non-managerial position with a $40 \%$ reduction in pay. His employer considered that he had committed a serious breach of the Equal Opportunities Policy and that the comments 'had the potential to cause offence' and that they 'could be seriously prejudicial to the reputation of the Trust'. He claimed that the trust had committed a breach of contract in demoting him. He did not bring a case for unfair dismissal because he did not have the funds to do so until the time limit to bring such proceedings had expired. ${ }^{71}$

In deciding the case, the High Court focused on the terms of the employment contract and did not directly consider his rights to freedom of expression or religion. However, the Court identified the relevant factors for this discussion and correctly held that in demoting him Trafford Housing Trust had breached his contract of employment. Briggs J said that he had come 'without difficulty' to the conclusion that 'his moderate expression of his particular views about gay marriage in church, on his personal Facebook wall at a weekend out of working hours, could not sensibly lead any reasonable reader to think the worst of the Trust for having employed him as a manager' and thus he did not bring the Trust into disrepute. It was held that his expression of his views could not 'objectively be described as judgmental, disrespectful or liable to cause discomfort, embarrassment or upset.'

In considering the nature of the speech and its likely effects, Smith therefore demonstrates a 'principled and sensible approach'.72 The expression was on a matter entirely unconcerned within his work. The mere fact that he listed his job, among other things, on his Facebook page and that some of his colleagues were his Facebook friends did not strongly link his expression to his employment. Furthermore, the subject of

\footnotetext{
70 Ibid. [4].

71 The limit is 3 months as opposed to 6 years for breach of contract claims.

${ }^{72}$ D. McGoldrick, 'The Limits of Freedom of Expression on Facebook and Social Networking Sites: A UK Perspective' (2013) 13 HRLR 125, 149.
} 
same-sex marriage, and more precisely same-sex marriage in religious premises, is an important matter of public interest and debate. It should not be entirely restricted on the ground it might cause offence, as this would greatly affect the right to freedom of expression. It should be noted that Smith's explanation of his views actually accorded with the position the law took: it was widely recognised that requiring religious institutions to perform same-sex marriages would violate their religious freedom.

Where though there is a clear link between the expression and the employment, the fact that it takes place out of work becomes less relevant. This is particularly true where the expression is offensive because it is aimed at a particular employee, rather than a general discussion on a matter of public debate. In such circumstances the public interest in ensuring debate is usually very minimal and the level of distress caused by such expression will presumably be higher.

Joseph $v$ TeleTech $U K L_{t d^{73}}$ is an example of such low value expression. Joseph stated on Facebook: 'quick question who in Teletech has A [a colleague] not tried to fuck? She does get around!'. Far from deleting the comment when A requested he do so, he made another derogatory comment about her on Facebook. He was dismissed on the basis that he had harassed A and brought the company into disrepute. The Tribunal held that his Article 10 rights were not engaged and he failed in his claim of unfair dismissal.

While the Tribunal may be right to argue that the right of freedom of expression does not entitle the claimant to make comments which damage the reputation or infringe the rights of $A,{ }^{\prime} 74$ it is difficult to agree with its conclusion that Joseph's Art 10 rights were not engaged. He was subject to a severe detriment, the loss of his job, because of his expression. Nevertheless, the comments merely involved abusive lowlevel speech which could clearly have the effect of violating A's dignity, and so the Tribunal's decision was correct. Harassing comments may evidently be hurtful regardless of whether they are made in or outside work time. It is also relevant that

73 (2012) NIIT/00704_11IT. Discussed in McGoldrick ibid.

${ }^{74}$ Joseph ibid. [6]. 
Joseph specifically mentioned his employer and thus the comments could be reasonably perceived as affecting TeleTech's reputation.

In summary, employers' control of out of work expression should be far more limited than work-time expression. Restrictions can have a potentially extreme effect on freedom of expression and considerably affect an employee's autonomy. If the expression concerns a matter of public debate there should be a strong presumption that employees should not be disciplined for such speech, even if it is offensive. Where statements are not about a matter of public debate, such as where abusive comments are aimed at particular colleagues, as in TeleTech, the presumption against restricting freedom of expression is less strong, but the general importance of the right should still be considered. This is not to suggest a strict dichotomy between the two situations. Some cases will fall between these two situations, for example where homophobic comments are made about the introduction of same-sex marriage to a gay colleague. Nevertheless, it provides a starting point for consideration of these issues.

\section{CONCLUSION}

It is not a cause for concern that discussion, consistent with the fact of a pluralist democracy, will take place in workplaces on controversial issues and that some of the opinions expressed will cause offence. Workplaces should not be 'sanitised' or made into 'sterile zones'. ${ }^{75}$ Employees also cannot always be expected to put their points across in the least offensive manner. However, this does not mean that employers must permit all expression: it can certainly be disruptive and in some cases employers must intervene to prevent harm to other employees.

The picture painted by this article is a positive one, in that tribunals and courts have taken the demands of freedom of expression into account when considering these

\footnotetext{
${ }^{75}$ Schultz n 27 above.
} 
issues. However, difficulties remain, particularly regarding unfair dismissal claims. As Collins and Mantouvalou point out, domestic law merely requires freedom of expression to be taken into account in a consideration of reasonableness. It does not start from the position that any interference with freedom of expression must be justified. It therefore seems likely that, while the narrow issue in Redfearn has been addressed, cases will continue to arise which question how much protection should be given to freedom of expression within employment. 